\title{
THE AGRICULTURAL LAND SUTTABILITY AND AGROECOLOGICAT ZONING AS THE MAIN FACTORS FOR RURAL SPATIAL PLANNING IN KOSOVO
}

\author{
Afrim SHARKU ${ }^{1 *}$, Marianna POSFAI ${ }^{1}$, Valon GËRMIZAJ ${ }^{2}$, \\ Fatbardh SALLAKU ${ }^{3}$
}

UDK 631.164(497.115)

\begin{abstract}
The soil is an important non-renewable resource that is vital to human life. It supports terrestrial ecosystems such as biodiversity, fresh air and water, food security, cultural heritage and the built environment, representing a natural and an economical asset of a country. Appropriate scientific information is crucial for sustainable soil management by local, national and regional governing institutions. Productive land is a critical resource for food and biomass production. In a broader sense land resources, management is the implementation of land use planning, as agreed between and with the direct participation of stakeholders. It is achieved through political decisions; legal, administrative and institutional execution; demarcation on the ground; inspection and control of adherence to the decisions; solving of land tenure issues; settling of water rights; issuing of concessions for plant and animal extraction (timber, fuel wood, charcoal and peat, non-wood products, hunting); promotion of the role of women and other disadvantaged groups in agriculture and rural development in the area, and the safeguarding of traditional rights of early indigenous peoples. Land suitability categorization and the agro-ecological zoning are of essential importance for the decision making for justified developments in many policy areas including agriculture and spatial planning.
\end{abstract}

Keywords: land suitability, agro-ecological zoning, rural spatial planning, Kosovo

\section{INTRODUCTION}

Land is a delineable area of the earth's terrestrial surface, encompassing all attributes of the biosphere immediately above or below this surface including those of the

\footnotetext{
${ }^{1}$ Expert, NIRAS, Project: Implementation and Enforcement of Rural Spatial Planning, Kosovo, Rr.

Shaban Polluzha nr.3,10000 Prishtina, Kosovo

${ }^{2}$ Dardania College, Faculty of Architecture and Urban Planning, Rr. Ibrahim Lutfiu nr.17, Prishtina, Kosovo

${ }^{3}$ Agriculture University of Tirana, Kodër Kamëz, SH1, 1000 Tirana, Albania

*Corresponding author: afrim_sharku@yahoo.com
} 
near-surface climate the soil and terrain forms, the surface hydrology (including shallow lakes, rivers, marshes, and swamps), the near-surface sedimentary layers and associated groundwater reserve, the plant and animal populations, the human settlement pattern and physical results of past and present human activity (terracing, water storage or drainage structures, roads, buildings, etc.). According to MAFRD data $^{4}$, Kosovo is characterised as a rural region whereby approximately $60 \%$ of the population is living in rural areas with an approximated $35 \%$ of the entire labour force involved with farming activities. Therefore, agriculture represents a key strategic sector for employment and economic activity. Compared to the 1990s, agricultural production has increased in the third millennium through government's commitment to improve the overall agricultural development.

Currently, in Kosovo, a land categorization system is used, which is based on the soil analysis undertaken fifty years ago and it was primarily used for the visual mapping of land use for land taxation purposes. It is based on the fundamental principle that a specific land use type is associated with a particular land quality class. Land suitability categorization and the agro-ecological zoning are of essential importance in decision making for justified developments in many policy areas including agriculture and spatial planning. Kosovo has good quality soils ${ }^{5}$, which could be the foundation for a thriving agricultural industry that could sustain a significant impact on the country's GDP. However, because of the lack of spatial planning documents related to rural zones, the prime agricultural land was used for other purposes and construction that resulted in an immense loss of arable land.

This paper is intended to describe the role of the land suitability categorization and the agro-ecological zoning in the rural spatial planning process in Kosovo. The primary objective of the paper is to identify the relationship between land suitability categorizations, the agro-ecological zoning and land tenure on rural spatial planning and environmental impact in Kosovo.

The paper also aims to ensure widespread awareness among all stakeholders on the prevailing challenges of resource rural spatial planning and the importance of participatory and interactive intervention process for the rural land sustainable management. A systems approach is used to describe land suitability categorization and agro-ecological zoning in Kosovo, addressing the complex and dynamic nature of the relationships among the subject matter areas.

\footnotetext{
${ }^{4}$ Ministry of Agriculture, Forestry and Rural Development (2014), Green Report 2014, Prishtina Kosovo.

${ }^{5}$ EULUP Project Number 2010/230-489, Further Support to Land Use - Eulup, Agricultural Land

Suitability Classification, Technical Report No.3, Prishtina, 2011
} 


\section{MATERIAL AND METHODS}

Agriculture Land Suitability Classification methodology is described in details in Administrative Instruction No. 02/2012 On Classification of Suitability of Agriculture Land, prepared by Ministry of Agriculture Forestry and Rural Development, Kosovo ${ }^{6}$

The agro-ecological zoning methodology has been refined by FAO for within-country level zoning applications ${ }^{7}$, where socio-economic conditions were also taken into account. These conditions figure even more prominently in the programmes for (agro-)Ecological and (socio-)Economic Zoning EEZ - of whole and mainly natural ecosystems, such as the Amazon forest region or "biome". In these latter two cases, the zoning sensustrictu is a delineation of areas of rural lands, which could be earmarked for one or another use or non-use, based on identical physio-biotic conditions and prevailing socio-economic infrastructure. The resulting units can be defined as Resource Management Domains, RMDs, defined as areas within a broad physio-biotic zone that have at present the same socio-economic conditions.

Agricultural land suitability classification is crucial information set for spatial planning. A land suitability categorization is of essential importance in decision making for planning justified developments in many policy areas including agriculture and rural spatial planning in general. Land suitability classes from $1^{\text {st }}$ to $8^{\text {th }}$ are used as a basis for policy implementation and management in many sectors such as agriculture, forestry, construction, environment, real estate market, taxation, spatial planning, and development. Kosovo has widespread good quality soils, which could form the basis of a thriving agricultural industry which could constitute an important part of the country's GDP. However because of unplanned developments that have not been sanctioned by the state this area of prime quality land is rapidly reducing. Furthermore, the segregation of land parcels, the small average farm size restraints land reform and directly affects the economic value and effectiveness of the agricultural sector.

These are the primary arguments why Kosovo needs to implement a refined and updated system of assessing land suitability for agriculture, which can also be used as a tool to inform policy decisions in the agricultural sector and spatial planning. This system is based on all currently available data and takes account of physical land properties. Bearing in mind the urgently pressing issues facing Kosovo, in order to ensure rapid integration into policy systems, the new land suitability classification ${ }^{8}$ is straight forward, clear, transparent and easy to apply.

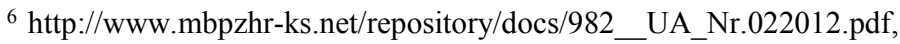

${ }^{7}$ FAO, 1996. Agro-ecological Zoning. FAO Soils Bulletin 73, Food and Agriculture Organization of the United Nations, Rome, Italy

${ }^{8} \mathrm{http} / / /$ www.mbpzhr-ks.net/repository/docs/982_UA_Nr.022012.pdf,
} 
It is the first time that the Kosovo municipalities will do integrated zoning planning for the rural areas within their territories ${ }^{9}$.

\section{RESULTS AND DISCUSSION}

Physical planning is the designing of the optimal physical infrastructure of an administrative land unit, such as transport facilities - roads, railways, airports, harbours; industrial plants and storage of produce; mining and power generation, and facilities for towns and other human settlements - in anticipation of population increase and socioeconomic development, and taking into account the outcome of land use zoning and planning. It has both rural and urban development aspects, though the latter usually predominates. Physical planning is generally carried out by the state, or by local government organizations for the general good of the community. The purpose is to take a more nearly holistic or overall view of the development of an area that can or would be taken by individuals. Physical planning has two main functions: to develop a rational infrastructure, and to restrain the excesses of individuals in the interests of the community as a whole. This latter function usually leads to physical planning being associated with a system of laws and regulations.

Land use planning is mainly related to rural areas, concentrating on the utilization of the land in the broadest agricultural context (crop production, animal husbandry, forest management/silviculture, inland fisheries, safeguarding of protective vegetation and biodiversity values). However, peri-urban areas are also included where they directly impinge on rural areas, through expansion of building construction onto valuable agricultural land and the consequent modification of land uses in the adjoining rural areas.

In a broader sense land resources, management is the implementation of land use planning, as agreed between and with the direct participation of stakeholders. It is achieved through political decisions; legal, administrative and institutional execution; demarcation on the ground; inspection and control of adherence to the decisions; solving of land tenure issues; settling of water rights; issuing of concessions for plant and animal extraction (timber, fuel wood, charcoal and peat, non-wood products, hunting); promotion of the role of women and other disadvantaged groups in agriculture and rural development in the area, and the safeguarding of traditional rights of early indigenous peoples.

The agriculture land suitability classification system is based on the assumption that land is used for conventional mechanized arable agriculture without irrigation. Agricultural land suitability takes account the spatial variation of all soil properties, landscape settings and climate conditions across the whole of Kosovo.

The key soil properties that determine ALSC are those that influence: (i) workability of landthat is the ability to produce a good seed bed at the correct time of year for the crop and to allow harvesting in conditions that will not damage soil structure, and (ii) crop water

\footnotetext{
${ }^{9}$ Assembly of Republic of Kosovo, Law No. 04/L-174, on Spatial Planning, 2013 Prishtina, Kosovo
} 
availability- that ensures there are sufficient water reserves in the soil at key times of the year to allow optimum crop growth. Soil texture, soil depth, stoniness, available and retained water capacities and the depth and duration of waterlogging in the soil, therefore, are the main soil properties determining the suitability of land for arable cropping. The most important terrain factor is slope angle, though length and shape of the slope are also relevant. Regarding climate, rainfall, temperature, potential transpiration and derived water balance information are the most important factors.

This simple pragmatic methodology has been developed for Kosovo and it is based on all available data and carefully adjusted to the scale suitable for municipal spatial planning. The mapping methodology can be readily applied and more importantly - it can be accurately replicated by non-specialist staff in all municipalities or throughout Kosovo.

This ALSC methodology is suitable for national and municipality scale and to all readily available data. It comprises three 'Key Datasets' describing soil, terrain and climate. Four ALSC factors were selected from the soil data, two from climate data and one factor represents terrain. As it is the general case elsewhere in Europe, the geology substrate has not been considered in the ALSC model. Geological deposits act as parent material in soil formation process, but soil layers themselves are of utmost importance for ALSC because arable agriculture activities are usually done in 30-40 cm depth and are not possible in deeper laying parent material.

Some of these seven factors are more important than others in determining ALSC. The table of the relative importance of ALSC factors has been compiled (Table 1). Collective well experienced international expertise suggests that the main driver of this ALSC model is soil information (the 4 soil factors together represent 0.65 points of total importance, where maximum sum of points is equal to 1), and supplemented by factors describing terrain - slope (representing 0.25 points of importance) and climate - annual average rainfall and altitude (each representing 0.05 points of overall importance) $)^{10}$.

Table 1. Factors for calculation of Agricultural Land Suitability Classification ALSC

\begin{tabular}{llc}
\hline Key Datasets & Factors & $\begin{array}{c}\text { Relative importance of } \\
\text { factors for ALSC }\end{array}$ \\
\hline \hline Soil & Soil type & 0.45 \\
\hline & Soil texture & 0.05 \\
\hline & Soil depth & 0.10 \\
\hline & Soil drainage & 0.05 \\
\hline
\end{tabular}

${ }^{10}$ Administrative Instruction No. 02/2012 on Classification of Suitability of Agriculture Land, Government of Kosova, Ministry of Agriculture, Forestry and Rural Development Prishtina, 2012. 


\begin{tabular}{llc}
\hline Key Datasets & Factors & $\begin{array}{c}\text { Relative importance of } \\
\text { factors for ALSC }\end{array}$ \\
\hline \hline Terrain & Slope & 0.25 \\
\hline Climate & Altitude & 0.05 \\
\hline & Av An Rainfall & 0.05 \\
\hline & Total & $\mathbf{1 , 0 0}$ \\
\hline
\end{tabular}

Table 2. Table of Agriculture Land Suitability Classification

\begin{tabular}{cccl}
\hline $\begin{array}{c}\text { Classes } \\
\text { SAL }\end{array}$ & $\begin{array}{c}\text { The points } \\
\text { SAL }\end{array}$ & $\begin{array}{c}\text { Suitability of } \\
\text { Agriculture Land }\end{array}$ & \multicolumn{1}{c}{ Group of Agriculture Land } \\
\hline \hline 1 & $85-100$ & $\begin{array}{l}\text { Very good } \\
\text { Good }\end{array}$ & Kept particularly for agriculture production \\
\hline 2 & $76-85$ & $\begin{array}{l}\text { Above } \\
\text { average }\end{array}$ \\
\hline 3 & $66-75$ & Average & \\
\hline 4 & $56-65$ & $\begin{array}{l}\text { Below } \\
\text { average }\end{array}$ & $\begin{array}{l}\text { Decisions to protect the agriculture must be } \\
\text { taken based on the value }\end{array}$ \\
\hline 5 & $46-55$ & Poor & $\begin{array}{l}\text { Weak land: mainly forestry zone and } \\
\text { meadows; it is not reasonable to be kept for } \\
\text { agriculture }\end{array}$ \\
\hline 7 & $36-45$ & Very poor & $\begin{array}{l}\text { Mechanized agriculture ploughing is not } \\
\text { possible }\end{array}$ \\
\hline 8 & $01-35$ & Unsuited & \\
\hline
\end{tabular}

Calculation of the SAL points is explained in details in Administrative Instruction No. 02/2012 On Classification of Suitability of Agriculture, in which case applies logarithm:

$$
\mathrm{ALS}=\mathrm{A} * \mathrm{Wa}+\mathrm{B} * \mathrm{~Wb}+\mathrm{C}^{*} \mathrm{Wd}+\mathrm{D} * \mathrm{Wd}+\mathrm{E}^{*} \mathrm{We}+\mathrm{F} * \mathrm{Wf}+\mathrm{G} * \mathrm{Wg}
$$

A = points for factor "Soil type"

$\mathrm{B}=$ points for factor "Soil texture"

$\mathrm{C}=$ points for factor "Soil depth"

$\mathrm{D}=$ points for factor "Soil drainage"
$\mathrm{E}=$ points for factor "Slope"

$\mathrm{F}=$ points for factor "Altitude"

$\mathrm{G}=$ points for factor "Av An Rainfall"

$\mathrm{W}[\mathrm{a} . . \mathrm{g}]=$ assessment of factors (Relative importance of factors for ALSC) 


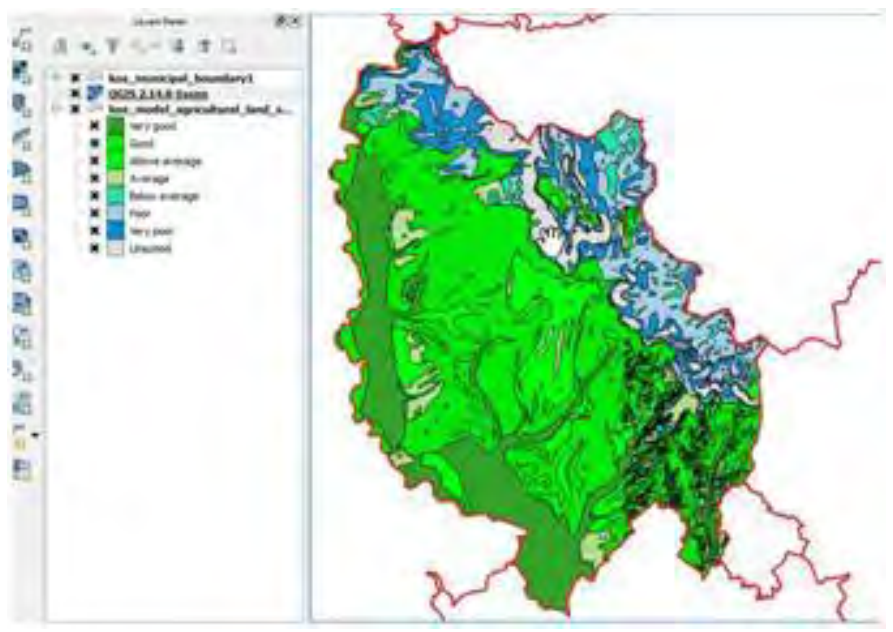

Figure 1. Map of ALSC of Rahovec Municipality

Agro-ecological Zoning (AEZ) refers to the division of an area of land into smaller unites, which have similar characteristics related to land suitability, potential production, and environmental impact ${ }^{11}$. It uses the agricultural land suitability classification ALSC as input and uses an additional set of data in its analysis. The output is an information set for the area involved, where the land is divided into land units (see Figure 2), according to their optimal land use regarding productivity, about socio-demographic and environmental factors. From the AEZ framework contains three essential elements:

(i) selected agricultural production systems with defined input and management relationships, and crop-specific environmental requirements and adaptability characteristics (these are termed land utilization types (LUT); (ii) geo-referenced climate, soil and terrain data which are combined into a land resources database, and (iii) procedures for the calculation of potential yields and for matching crop/LUT environmental requirements with the respective environmental characteristics contained in the land resources database, by land unit and grid-cell.

${ }^{11}$ Ministry of Environment and Spatial Planning Kosovo (2015), A Guide for Rural Spatial Planning in Kosovo, Prishtina, Kosovo. 


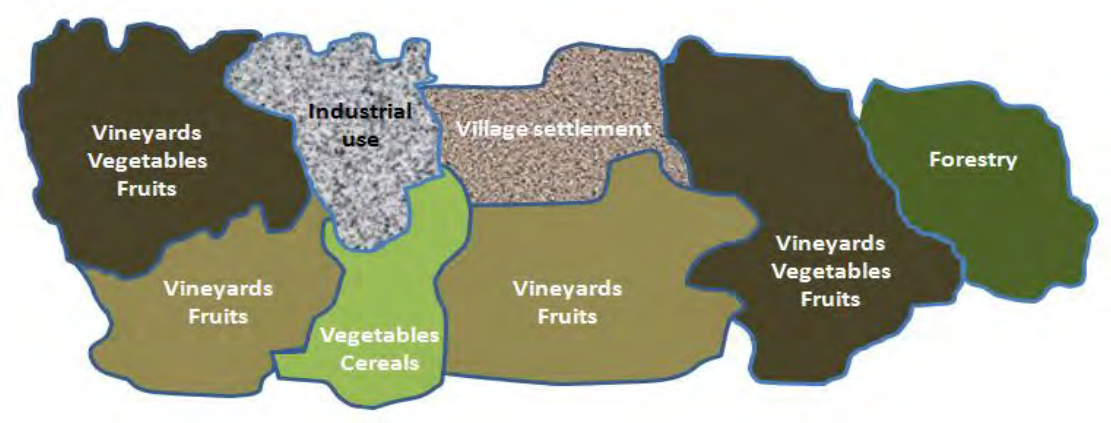

Figure 2. Examples of land units

Based on such methodology, each municipality has the potential area suitable for the cultivation of specific crops. Definition of the manner of land use in each unit should be done through socio-economic analysis of the needs of the population of the municipality and making an analysis of market requirements. After these two analyzes based on the potential of the soil, have to decide for what the defined surfaces during agro-ecological zoning would be exploited. Besides, creating an inventory and planning a sustainable development of agricultural land, one of the main objectives of the Agroecological zoning in Kosovo is to inform the potential investors about the agricultural potential of the land that is situated in the respective municipalities. In turn, the potential investors would have an important impact in the future land tenure and consolidation of the agricultural land, which is determined by increasing the agricultural productivity.

\section{CONCLUSIONS}

Kosovo has widespread good quality soils, which could form the basis of a thriving agricultural industry which could constitute an important part of the country's GDP. However because of unplanned developments that have not been sanctioned by the state this area of high-quality land is being rapidly reduced. Furthermore, the segregation of land parcels and the small average farm size restraints land reform and directly affects the economic value and effectiveness of the agricultural sector. A land suitability categorization is of basic importance in decision making for planning justified developments in many policy areas including agriculture and spatial planning.

The use of agro-ecological zoning is a good manner to identify the actual potential of agricultural land for development of specific annual crops and livestock in Kosovo. It consists of zoning the agricultural land into smaller units that have similar characteristics based on their land suitability attributes potential production and environmental impact. Through using the agro-ecological zoning, we can create an 
inventory of agricultural land that would provide valuable data related to agricultural assets of the municipality to potential investors that are interested in cultivating specific crops. Agro-ecological zoning is not a regulatory tool that determines a legally-binding land use. It is a guiding tool that exposes the true potential of specific zones in relation to its agricultural yield and according to climate, soil and terrain parameters that have a direct impact on agricultural production of specific crops. This type of zoning consists of the development of a standardized framework for the characterization of climate, soil and terrain conditions relevant to agricultural production. In this context, the concepts of Length of Growing Period (LGP) and of latitudinal thermal climates have been applied in mapping activities focussing on zoning at various scales, from sub-national to the global level.

The agricultural land suitability and agro ecological zoning are the main factors, which should take into consideration during the rural land management planning RLMP. This process incorporates integrated environmental planning into land use management, and at the same time is a highly flexible planning methodology that focuses on the economic and social needs of the local stakeholders.

Agricultural land is a production commodity, and farmers need sufficient flexibility to adapt to the demands and opportunities of the agricultural (local, regional and global) markets. At the same time, the management of environmental resources - like an available river- or ground water - requires detailed fine-tuning and locally integrated solutions. That is where rural land management planning serves to complement the (strategic) rural development planning and spatial planning zoning.

\section{REFERENCES}

Administrative Instruction No. 02/2012 on Classification of Suitability of Agriculture Land, Government of Kosova, Ministry of Agriculture, Forestry and Rural Development Prishtina, 2012.

Administrative Instruction No. 41/2006, On Change of Use of Agricultural Land, Government of Kosova, Ministry of Agriculture, Forestry and Rural Development Prishtina, 2006.

Assembly of Republic of Kosovo, Law No. 04/L-174, on Spatial Planning, 2013 Prishtina, Kosovo.

EULUP Project Number 2010/230-489, Further Support to Land Use - Eulup, Agricultural Land Suitability Classification, Technical Report No.3, Prishtina, 2011.

FAO, 1996. Agro-ecological Zoning. FAO Soils Bulletin 73, Food and Agriculture Organization of the United Nations, Rome, Italy. 
Global Agro-Ecological Zones Assessment: Methodology and Results, Interim Report IR00-064, International Institute for Applied Systems Analysis, November, 2000.

Ministry of Agriculture, Forestry and Rural Development (2014), Green Report 2014, Prishtina, Kosovo.

Ministry of Environment and Spatial Planning Kosovo (2015), A Guide for Rural Spatial Planning in Kosovo, Prishtina, Kosovo. 